University of Nebraska - Lincoln

DigitalCommons@University of Nebraska - Lincoln

Congreso internacional sobre iconografía

precolombina, Barcelona 2019. Actas.

$7-20-2020$

\title{
Tradiciones plásticas y ontologías: problemas en torno al estudio de la iconografía del período Medio del NO. Argentino
}

María Alba Bovisio

Follow this and additional works at: https://digitalcommons.unl.edu/actas2019

Part of the American Material Culture Commons, Indigenous Studies Commons, Museum Studies Commons, Other History of Art, Architecture, and Archaeology Commons, and the Other Languages, Societies, and Cultures Commons

This Article is brought to you for free and open access by the Zea E-Books at DigitalCommons@University of Nebraska - Lincoln. It has been accepted for inclusion in Congreso internacional sobre iconografía precolombina, Barcelona 2019. Actas. by an authorized administrator of DigitalCommons@University of Nebraska - Lincoln. 


\title{
Tradiciones plásticas y ontologías: problemas en torno al estudio de la iconografía del período Medio del NO. Argentino
}

\author{
María Alba Bovisio \\ Facultad de Filosofía y Letras. Instituto de Historia y Teoría del Arte “Julio E. Payró”. Universidad de Buenos Aires-Argentina. \\ mariaalbab@yahoo.com.ar
}

\begin{abstract}
Resumen
En este trabajo se analizan piezas producidas entre los siglos VII-XI, en el valle de Hualfín (Catamarca, Argentina) con fines cúlticos y ceremoniales, que presentan una iconografía de notable complejidad. Al respecto se propone indagar: el posible significado de las imágenes metafóricas y metonímicas que articulan humanos, felinos, saurios y reptiles, en relación al poder sagrado (lowaka) y, el rol que juega cada "tradición plástica” (escultores, grabadores, pintores) en la materialización, a través de los objetos e imágenes, del orden ontológico y cosmológico vigente en las comunidades del noroeste argentino en época prehispánica.
\end{abstract}

Palabras claves: iconografía del NOA prehispánico, ontologías, metáforas animales, tradiciones plásticas, wakas

\begin{abstract}
In this paper are analyzed pieces, produced during the Middle Period (600-1000 A.C) at Hualfin Valley (Catamarca, Argentine Northwest), which were used in cults and ceremonies and presents a very complex iconography. In this regard it is proposed to inquire the possible meaning of images that articulate human beings, feline, saurus and reptiles, in relation to the sacred power (waka) and, the role played by each "plastic tradition" (sculptors, engravers, painters) in the materialization, through objects and images, of the ontological and cosmological order in force in the Argentine Northwest communities in pre-Hispanic times.
\end{abstract}

Keywords: Argentine Northwest pre-Hispanic iconography, ontologies, animal metaphors, plastic traditions, wakas
Orman

En la investigación desarrollada en mi tesis doctoral (presentada en 2008) abordé un análisis exhaustivo de la producción plástica del Período Medio del NO. Argentino (600-1000 d.C.), atendiendo a las características particulares que asumía el discurso iconográfico tanto en relación con lo producido en los distintos valles, como respecto a las variaciones ligadas a las distintas materialidades (cerámica, piedra, metal).

El período Medio fue identificado con la cultura de La Aguada, definida en los años 60 por Alberto Rex González, quien, a partir de la producción cerámica, estableció tres estilos asociados a sectores geográficos: sector septentrional, centrado en valle Hualfin pero que abarca también el de Abaucán y la serranía del Ambato por el oeste, sector meridional desde el límite de Catamarca con La Rioja y hasta límite de esta provincia con San Juan, y sector oriental, desde el norte del valle de Catamarca hasta el límite con Tucumán. La existencia de estos sectores diferenciados implicaría no solo variaciones estilísticas sino diferenciaciones socio-culturales en el seno de la cultura de La Aguada (González 1964). Posteriormente, siempre a partir de la cerámica, diferenció nuevos estilos al interior de los tres sectores definidos: Ambato negro-grabado, Ambato tricolor, Portezuelo, Hualfin gris grabado, Hualfin pintado y Aguada meridional (González 1998).

Publicado en Congreso internacional sobre iconografía precolombina, Barcelona 2019. Actas, Victòria Solanilla Demestre, editora (Lincoln, Nebraska: Zea Books, 2020). https://doi.org/10.32873/unl.dc.zea.1257 
La labor desarrollada por otros investigadores en distintos sitios de "ocupación Aguada" ha permitido plantear que más que de una cultura unificada se trataría de distintas entidades socio culturales que compartían un sustrato de creencias comunes a todo el mundo surandino (Pérez Gollán 1994, Pérez y Heredia 1991) y que tuvieron expresiones específicas según los antecedentes históricos y culturales locales (Nuñez Regueiro y Tartusi 1987, 2002). De acuerdo a las interpretaciones propuestas desde la arqueología, en las últimas décadas, se ha consolidado la tesis de que cada valle tuvo modos de organización y procesos de configuración socio-culturales diferentes, pero aún es objeto de debate la caracterización de estas organizaciones y de los procesos de complejización social. ${ }^{1}$ Sin embargo, hay consenso acerca de que los grupos se organizaban bajo la autoridad de jefes o curacas chamanes.

Respecto del contexto de uso y circulación de las piezas analizadas en mi tesis, en algunos casos es conocido y en la mayoría, inferido, puesto que provienen de excavaciones no científicas que lo han destruido. Se trata de espacios funerarios y/o ceremoniales (a veces superpuestos a espacios domésticos) y, en algunos casos, la morfología de los objetos evidencia determinadas funciones (pipas, morteros, pucos, por ejemplo). Todo el corpus presenta una iconografía que denota una riqueza y complejidad simbólica fundada en los procedimientos retóricos de la metáfora, operación de sustitución fundada en una analogía, y la sinécdoque, operación por la cual se alude a un todo a través de una de sus partes, atributos o rasgos característicos. Al respecto, la pregunta inicial que condujo mi investigación (en diálogo con las investigaciones pioneras de A. R. González y las desarrolladas a posteriori por diversos investigadores ${ }^{2}$ ) giró en torno al posible rol y significado de las imágenes que integraban humanos con felinos, saurios y serpientes, animales cazadores, poseedores de capacidades suprahumanas en común- ver en la oscuridad, invisibilizarse al mimetizarse con el medio ambiente, poseer "armas" letales en su propia anatomía (garras, colmillos, veneno, etc.)- en relación a la autoridad político-religiosa. El análisis de las diversas formas en las que en las imágenes se ponen en juego asociaciones entre estos animales entre sí y con el humano, me permitió construir hipótesis específicas sobre el sentido de los motivos iconográficos en relación a los usos y funciones de los objetos en los que se plasman. Al respecto planteo que la trasformación chamánica, si bien es clave a la hora de interpretar estas iconografías, no agota su significación, y propongo lecturas diferenciadas atendiendo a cómo se articulan los procedimientos retóricos a través de los cuales estas se configuran, con las funciones de los objetos en los que se manifiestan, y las técnicas y materiales con los que se producen dichos objetos. A mi juicio, el sentido surge y se constituye en esa trama que incluye los usos y circulaciones de imágenes encarnadas en objetos.

Por otra parte, durante el desarrollo de la investigación doctoral, no solo detecté claras diferencias iconográficas de una materialidad a la otra, piedra, metal, cerámica, sino dentro de una misma materia, y me di cuenta que jugaba un rol muy importante lo que denominé "tradición plástica": una cerámica pintada me hablaba del modo en que los ceramistas pintores interpretaban una cosmología compartidas, mientras que en la cerámica grabada podía "ver" la versión de los ceramistas grabadores. Cada tradición plasmaba una misma temática iconográfica pero con variantes estilísticas que le imprimían un sesgo particular, que estaría en estrecha relación con los modos propios de expresar el orden cosmológico vigente en las comunidades de cada valle. Los pintores, grabadores, escultores eran quienes tenían el poder, a través de sus "saberes plásticos", de formalizar un discurso en imágenes que daba cuenta de ese orden.

Cabe aclarar que, siguiendo a Descola, defino ontología como un sistema de distribución de propiedades entre las entidades existentes en el mundo (humanos y no humanos) y cosmología como la concepción del mundo producto de esa distribución de propiedades, que implica determinadas relaciones entre esas entidades (Descola 2005).

En relación a esto, en los últimos años encaré la problemática planteada por Descola en Le fabrique des images, acerca de la relación entre los esquemas ontológicos, que rigen el orden social, y las lógicas que se ponen en juego al construir imágenes, vale decir, la relación entre ontologías y modos de "representar" o "figurar" (Descola 2011). En este sentido, si mi motivación inicial fue intentar "leer" las imágenes en tanto textos que expresaban una cosmología que ponía en juego interacciones

1. Algunos autores han insistido en la aparición de señoríos o jefaturas en particular en el área del valle de Ambato (Perez 1994, Lagens 2006) mientras que otros sostienen que se trató de organizaciones de tipo heterárquicas (Cruz 2005), en tanto que otros han problematizado la cuestión a partir de una exhaustiva revisión de las evidencias halladas (Gordillo 2007, 2013, 2018). 2. Fundamentalmente Pérez Gollán, Llamazares, Kusch, Gordillo, Callegari, Baldini, Sempé, Laguens, Marconetto. 


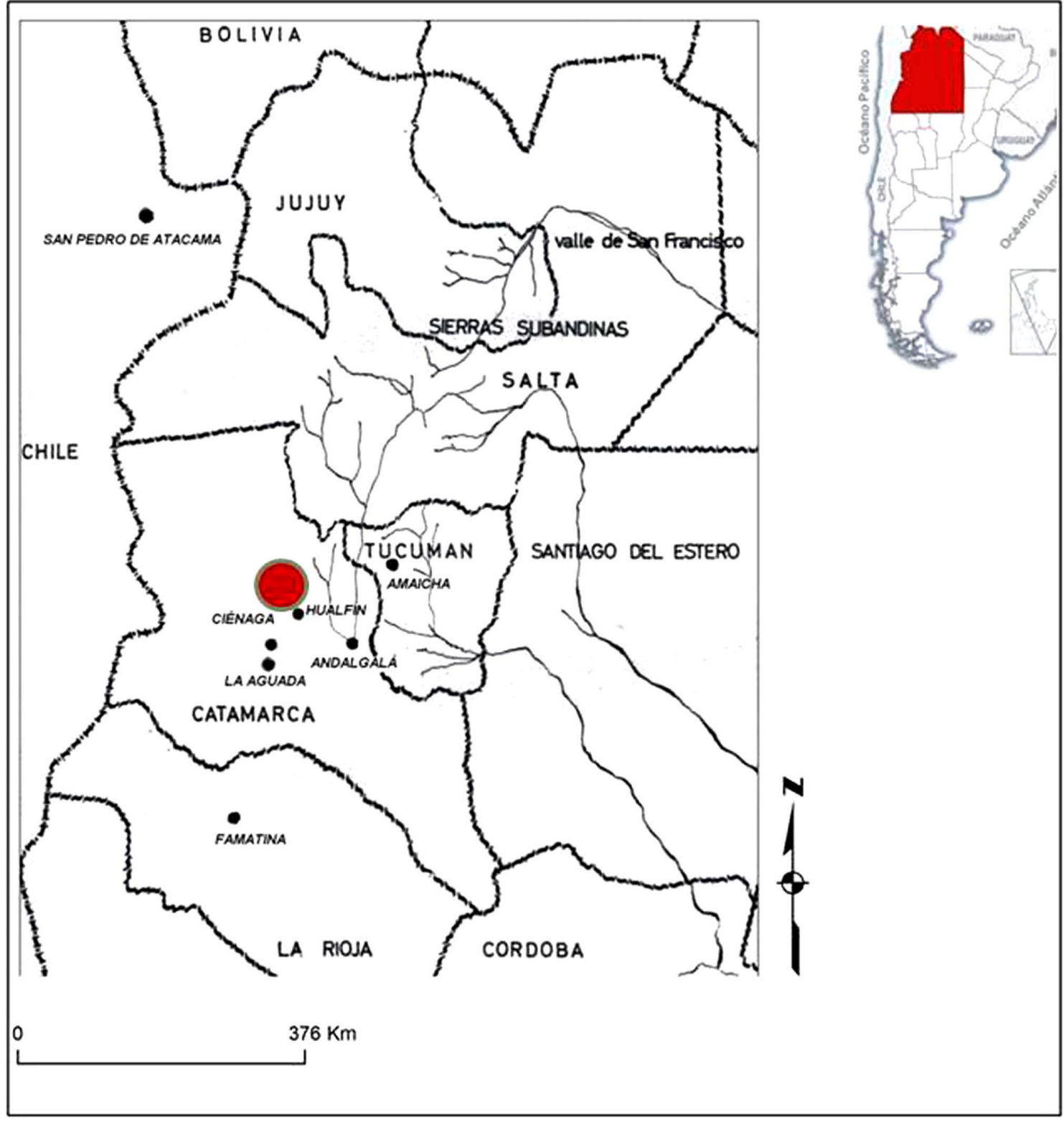

Figura 1: Mapa del NO argentino, ubicando el valle de Hualfín, Catamarca.

simbólico-metafóricas entre humanos y determinados animales, actualmente encaro esas imágenes, más que como "textos", como entidades "vivas" con agencias concretas (Gell 1998) que en sus diversos contextos de uso y circulación inciden en la configuración del orden ontológico y cosmológico.

En aras de acotar la discusión, en este texto me concentraré en el análisis de la cerámica policroma y la gris grabada producidas en el valle de Hualfín, Catamarca (figura 1) durante el Período Medio (600-1000 d.C.) ${ }^{3}$, centrado en los siguientes ejes:

1-qué operaciones cognitivas se ponen en juego en la construcción de imágenes fundadas en la metáfora y la sinécdoque.

2-qué seres se pueden identificar en la configuración de dichas imágenes y qué se connotaría al integrarlos en los diversos motivos iconográficos. 


\section{Imágenes plásticas, pensamiento visual y ontologías}

Varios autores han enfatizado la existencia de un "pensamiento visual" identificado con la percepción visual en tanto actividad cognitiva ${ }^{4}$. Vale decir, ver implica conocer y las imágenes mentales, que sirven de sostén al pensamiento, son creadas por cada grupo humano constituyendo esquemas cognitivos a través de los cuales se organiza lo real. En este proceso, que articula lo biológico y lo cultural, el lenguaje plástico expresa una forma específica de pensamiento irreductible a otras: el pensamiento plástico. Figurar, es decir, construir una imagen plástica, implica un proceso de representación dialéctica entre lo percibido, lo real y lo imaginario, "es integrar en un sistema, a la vez material e imaginario, elementos cuya yuxtaposición crea nuevos objetos susceptibles de reconocimiento, de unión y de interpretación..." (Francastel 1970: 25). Las imágenes plásticas proporcionan a las sociedades un instrumento específico para explorar el universo sensible, constituyéndose en uno de los modos mediante el cual los hombres dan forma a su universo, es decir, construyen conocimiento sobre él. Pero además, como señalé más arriba, estas son siempre, e ineludiblemente, materiales, son entidades constituidas en un entramado técnico-simbólico, que producen el mundo en tanto participan en la conceptualización de la realidad, expresando y al mismo tiempo configurando ontologías (Bovisio 2008 a y b). Son agentes que participan de las redes de relaciones que involucran, naturaleza, objetos y personas en un proceso de construcción del mundo en términos materiales y simbólicos (Gell 1998, Latour 2008, Godelier 1989).

Descola sostiene que la figuración es una operación universal por medio de la cual "un objeto cualquiera es investido de manera ostensible de una agencia socialmente definida" en tanto posee un potencial de evocación icónica de una prototipo real o imaginario (Descola 2006: 167). Coincido con el antropólogo francés respecto a su idea de "figuración" como operación aplicable a cualquier objeto que deviene imagen figurativa en tanto posee una agencia social pero disiento acerca de que el único modelo posible de esta agencia sea el del "signo icónico" es decir, un signo visual que evoca un prototipo real o imaginario identificado con un referente. Excede los alcances de este trabajo desarrollar esta discusión pero me interesa dejar planteado que las imágenes pueden funcionar no solo como "representación", signo que está en lugar de o que evoca un "prototipo", sino que se pueden constituir en realidades en sí mismas, "presentificaciones", que no remiten a un referente ausente (Bovisio 2019).

Ahora bien, hago mío el planteo de Descola acerca de que esa capacidad de agencia de las imágenes o figuraciones se funda en el hecho de que son "ontologías morfologizadas", dado que de cada ontología deriva una epistemología que guía una teoría de la acción. En este sentido, "preguntarse por los objetivos asignados a cada modo de figuración implica preguntarse cuáles son las características de cada configuración ontológica que van a ser objetivadas en la imagen" (Descola op. cit: 173). Figurar implica una morfología de relaciones ontológicas que se pone en evidencia. No se representa del mismo modo un animal percibido como una persona que como un emblema de cualidades o como un objeto sin "alma" (Descola 2011: p.17). Esto no debe entenderse como la postulación de una relación mecánica entre "estilos" y ontologías sino que las imágenes devienen "ontologías morfologizadas" en el seno de las sociedades que las producen y usan para informar (darle forma, ordenar, conocer) su mundo. En otras palabras, es en el contexto de producción, uso y circulación de los objetos/imágenes -resultantes del entramado de las dimensiones técnico-material con la iconográfica y la estilística- que sus modos de configuración expresan y constituyen órdenes ontológicos.

Propongo, entonces, en función de los ejes señalados más arriba, indagar, en el análisis de la cerámica grabada y la cerámica pintada del valle de Hualfín, dos aspectos: qué tipo de ontología estaría morfologizada en sus imágenes, y que rol jugaron estas en la trasmisión de saberes cosmológicos.

\section{Humanos, animales y quimeras}

Al abordar el análisis asumo como hipótesis de partida que:

1- los chamanes y productores de las piezas estaban en estrecha asociación, incluso pueden haber sido los mismos o pertenecer al mismo grupo de parentesco. La maestría con la que ha sido elaborada la mayoría de las piezas que circularon en contextos cúltico- ceremoniales evidencia hacedores

4. “No parece existir ningún proceso del pensar que, al menos en principio, no opere en la percepción. La percepción visual es pensamiento visual" (Arnheim 1985: 13). 
entrenados, profundos conocedores de técnicas, materiales y discursos iconográfico-simbólicos. Adquirir estos saberes demandaba tiempo lo que solo era posible si estos "artistas" gozaban, al igual que los curacas-chamanes, de algún tipo de privilegio que los eximiera (aunque sea en parte) de la producción de las materias primas que garantizaban el sustento de la comunidad; actividad que quedaba en manos del grueso de la población dedicado a tareas agro-pastoriles.

2-las prácticas chamánicas ocuparon un lugar clave en la organización socio-cultural, política y religiosa de las comunidades del NOA (al igual que en el resto del mundo andino). Existen evidencias arqueológicas y etnohistóricas (Pérez Gollán y Gordillo 1993, Llamazares 2000) que sustentan la importancia de estas prácticas asociadas al consumo ritual de alucinógenos, fundamentalmente de cebil ${ }^{5}$, disponible en los bosques de las sierras del Ancasti y en el sur del valle de Ambato, en la provincia de Catamarca. Este chamanismo asume una forma específicamente andina identificada con el culto a las wakas/ancestros, entidades sagradas multiformes que pueden encarnarse tanto en "objetos" como en seres de la naturaleza, y que remiten no solo lo divino sino al origen del grupo, y en este sentido, se pueden identificar con su ancestro fundador, que legitima los derechos de la comunidad sobre el territorio y garantiza la continuidad de la vida de todos los seres existentes en ese territorio (humanos, animales, plantas) ${ }^{6}$.

3- en las sociedades amerindias la configuración de una ontología, a partir de la cual se instaura una cosmología, se funda en la experiencia racional y emocional de la naturaleza, que confronta humanos y no-humanos. Al respecto, cabe aclarar, que cuando se concibe al NO argentino como espacio andino no se excluyen a las tierras bajas sino todo lo contrario: históricamente en los Andes se han dado interacciones entre la costa, la sierra y la selva ${ }^{7}$ y esta dinámica también involucró al NOA. Más allá de que aún es objeto de discusión entre los arqueólogos cómo se dio esa dinámica, indudablemente la selva ha sido (y es) para las sociedades valliserranas un espacio de interacción constante ${ }^{8}$.

Planteo, entonces, que a partir de la experiencia que los hombres tuvieron de determinados animales ${ }^{9}$, se configuraron iconografías quiméricas que expresaban y encarnaban el poder sagrado de las wakas, con las que los chamanes interactuaban o a las que encarnaban en el ritual ${ }^{10}$.

Defino imagen quimérica como la que resulta de una operación retórica que integra metáforas y sinécdoques; la particularidad de la quimera es que permite descifrar los diversos seres que la constituyen en un único ser híbrido. Desde mi perspectiva, esta alusión simultánea a lo uno y lo múltiple, donde lo uno es un ser supra natural

5. Anadenanthera colubrina, mimosa arborescente que crece hasta los $1200 \mathrm{msnm}$, alcanza una altura de 20 mts y su tronco un diámetro de $60 \mathrm{~cm}$., y cuyas semillas en vainas tienen propiedades psicoactivas; los polvos elaborados con esas semillas tostadas y molidas se pueden fumar o inhalar.

6. En varios trabajos me he explayado acerca del sentido de este concepto en el mundo andino y de la pertinencia de aplicarlo a las culturas del noroeste argentino prehispánico (Bovisio 2011, 2012b, 2016).

7. Basta, por ejemplo, atender a los magníficos textiles en plumaria procedentes de los desiertos costeros del Perú hechos con plumas de aves selváticas como el guacamayo.

8. En un reciente texto Marconetto (2015) sostiene que en la iconografía de La Aguada se incluyen referencias a plantas y, a propósito de su posible identificación, llama la atención acerca de la importancia de considerar la relación entre el ámbito de esa "cultura", los valles de Catamarca y La Rioja, y las tierras bajas.

9. Hace ya más de una década, la lectura de los trabajos compilados por Urton (1985) en el volumen Animal myths and metaphors in South America fue un disparador clave para empezar a indagar esta cuestión aplicada al análisis de las imágenes prehispánicas.

10. Mucho se ha discutido acerca de si determinadas "representaciones" son la "deidad" o el chamán en trance. A mi juicio la discusión es inconducente dado que no tenemos fuentes que permitan saldarla y tampoco tiene mayor importancia puesto que lo central es cómo se construye la imagen de la entidad sagrada, la waka, ya sea que corresponda a la imagen de la "deidad" en sí, ya sea que corresponda a la del chaman haciéndola presenten en el ritual de transformación; en uno u otro caso la imagen corresponde a la de la waka. Pero, además, postulo que las imágenes no son meras descripciones de eventos o prácticas sino la materialización de modos de concebir, pensar, conceptualizar, y es ese el nivel que pretendo abordar. En este caso concreto, el del concepto de "poder sagrado", lo waka. 


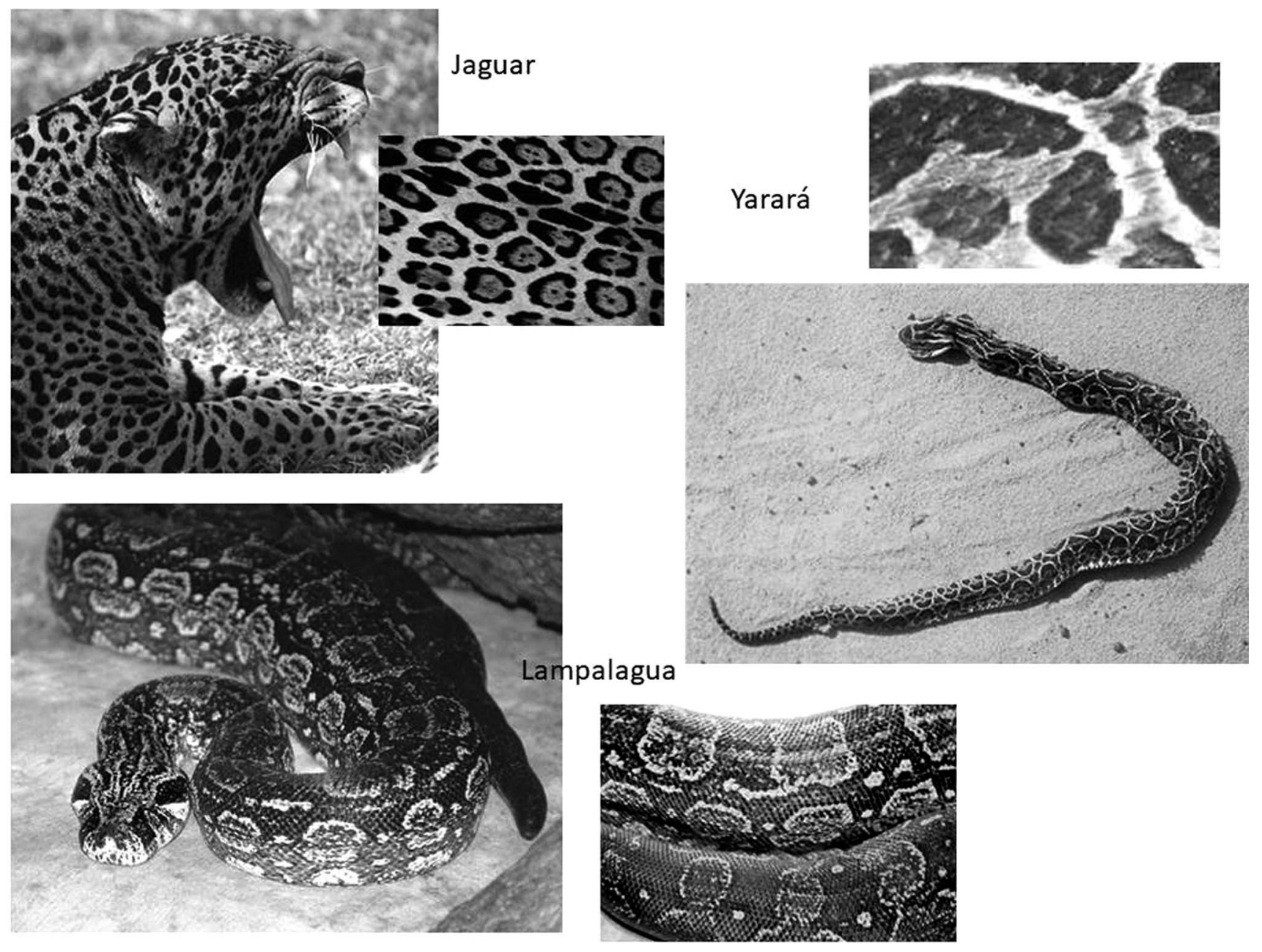

Figura 2: Jaguar, lampalagua y yararás. Fotos: Guido Pastorino, 2007.

(la quimera) y lo múltiple son los diversos seres reconocibles a través de rasgos observables en el mundo fáctico (natural), es fundamental en el carácter y sentido de este tipo de imagen que señala determinadas asociaciones y significaciones particulares entre esos seres de la naturaleza.

En el caso que nos ocupa, a partir de la confrontación de los motivos iconográficos con las características morfológicas de animales con los que los habitantes de la región valliserrana estuvieron en contacto (incluyendo los de las tierras bajas), planteo que:

- Se remite al jaguar (leo onca) a través de las manchas compuestas, rasgo distintivo de su pelaje (figura 2). Este animal es el felino más grande de América, alcanza 2,50 m de largo y $140 \mathrm{~kg}$ de peso, habita fundamentalmente en la zona de yungas (actualmente está en peligro de extinción) y antaño circuló por las zonas húmedas del faldeo oriental del valle de Ambato en Catamarca. Es un excelente nadador y puede cazar tanto en el agua como en la tierra.

- A las lampalaguas y yararás (figura 2), se alude a través de manchas compuestas (estas serpientes poseen un tipo de mancha similar a la de los jaguares), de reticulados romboidales que responden al patrón de su piel y de los cuerpos ondulantes o en zigzag (serpentinos). La lampalagua (boa constrictor occidentales) es de la familia de las boas, puede alcanzar hasta 2,50 m de largo, su diámetro oscila entre los 10 y $15 \mathrm{~cm}$ y posee unos dientes curvos que le permiten atrapar a su presa para luego deglutirla. La yarará (Bothrops alternata) es más chica, su largo máximo es de 1,70 m, pero es temible por el veneno mortal que inocula 


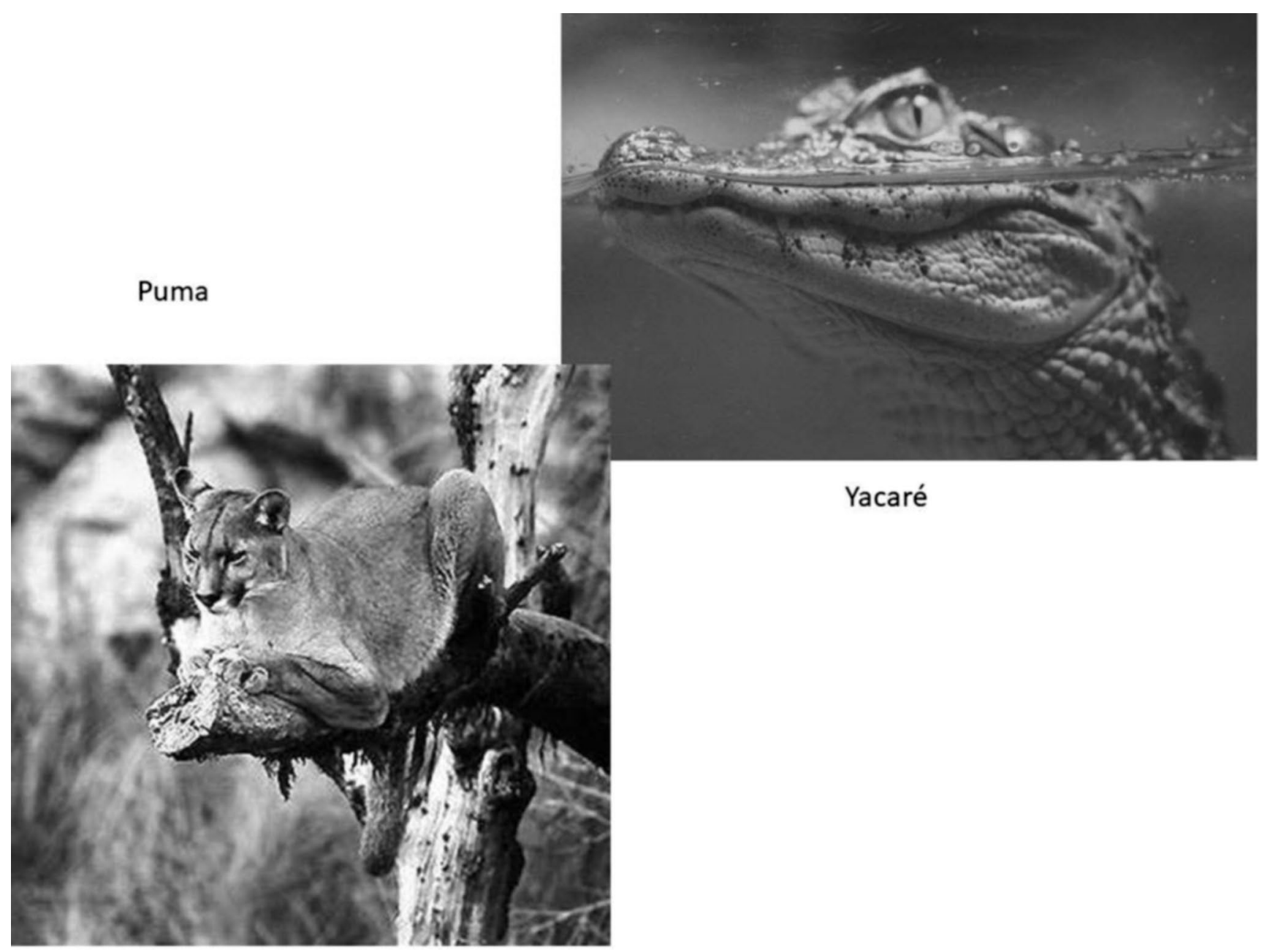

Figura 3: Puma y yacaré. Fotos: María Alba Bovisio y Guido Pastorino, 2007.

por medio de sus colmillos. Ambas habitan, y habitaron, tanto en la franja de yunga como en los valles de Catamarca y La Rioja.

- El otro felino al que se refiere en la iconografía es el puma (felis concolor), particularmente a través de las largas colas, atributo fundamental que le permite mantener el equilibrio cuando trepa, sobretodo hasta gran altura (figura 3). De todos los carnívoros de América este, que alcanza entre 1,50 y 2 m de largo, y cuyo peso oscila entre 40 y $100 \mathrm{~kg}$, es el que tiene distribución más amplia por su gran capacidad de adaptación a ambientes muy diversos: llanuras, montañas, selva húmeda, altiplano árido, de modo que compartió espacios comunes con el jaguar. En la colección Muñiz Barreto del Museo de La Plata se cuenta con una piel de puma procedente de un ajuar funerario prehispánico del valle de Aguada (Catamarca) de $2 \mathrm{~m}$ de largo (Cabrera 1961: 224) que posiblemente correspondería al período Medio.

- A través de las cabezas de ojos de círculos concéntricos, fauces aserradas y largas lenguas (figura 3), se alude al otro animal clave: el yacaré (caiman yacare). Conclusión a la que arribé a partir de la descripción de este animal hecha por el zoólogo Freiberg combinada con la observaciones directas de diversos ejemplares:

“[...] protegido el cuerpo con una sólida coraza, formada por escamas carenadas asentadas sobre bases óseas donde rebota el plomo de las balas, sin mellarla siquiera. La cabeza chata, rugosa con crestas salientes, 
exhibe en posición superior los ojos saltones y los orificios nasales, que le permiten flotar sobre el agua [...], asomando únicamente las pupilas verdosas. La boca inverosímil, como una hendidura tajante, $\underline{\text { desco- }}$ munal, provista de dientes agudos, cónicos [...] con lengua carnosa adherida, exhibe generosa el fondo de las fauces al menor asomo de enojo y descarga mordiscos formidables. Las patas poderosas provistas de garras, la cola aplanada transversalmente con una cresta dorsal, capaz de sacudir chicotazos impresionantes y cada órgano del animal parece creado para la lucha." (Freiberg 1954: 185-86).

En esta cita se destacan exactamente aquellas partes del yacaré ${ }^{11}$-el largo hocico dentado, la lengua carnosa, crestas- que se corresponden con la iconografía del draconiforme. Utilizo este término porque me resultó elocuente que el mismo autor en un pasaje de su texto utilizara la expresión "cabeza draconiana" al referirse a la cabeza de este animal (op. cit 189).

Este hidrosaurio, que puede alcanzar $4 \mathrm{~m}$ de largo y $90 \mathrm{Kg}$. de peso, habitó en las tierras bajas orientales de Santiago del Estero y zonas periféricas de yungas (actualmente, al igual que el jaguar, está en peligro de extinción).

Rydén (1944) publicó en los años cuarenta la fotografía de un peto de piel de yacaré hallado como parte del ajuar en una tumba en plena puna, en el sitio de Turi, en la región del Loa (Norte de Chile). Este dato abona la hipótesis de que este animal tuvo, en el contexto surandino, connotaciones mítico-religiosas ligadas a valores de poder y autoridad.

- Finalmente, asumo que la remisión a lo humano se efectúa a través de la cabeza antropomorfa y los cuerpos bípedos.

Propongo, entonces, que la iconografía de la cerámica aguada gira en torno a lo humano y a tres especies, que articulan las tierras altas y bajas, que tendrían connotaciones cosmológicas claves en relación al poder sagrado y el orden cósmico: los felinos (jaguar y puma), las serpientes (lampalaguas y yararás) y los yacarés (Bovisio 2008a, 2012 a y b). Se trata de animales que comparten una serie de rasgos que los hacen poseedores de propiedades suprahumanas: son cazadores crepusculares y nocturnos que pueden ver en la oscuridad (todos poseen pupila vertical), dueños de armas en su propia anatomía (garras, colmillos, veneno, etc.) y de fuerza, agilidad y/o velocidad extremas, que además, son capaces de mutar su piel y/o de mimetizarse con el medio.

Dentro de las iconografías quiméricas distingo los siguientes motivos:

1-Felino-draconiformes en la cerámica polícroma (figura 4 a) este motivo consiste en un cuadrúpedo con manchas formadas por círculos concéntricos y círculos reticulados, con "cabeza draconiforme" y larga cola que, generalmente, remata en ese mismo tipo de cabeza. En la cerámica grabada aparece el felino simple (figura 4 b) y el desdoblado, las manchas pueden ser círculos concéntricos o punteados, en algunos casos el cuerpo asume la forma de un arco que genera un contrapunto con el arco de la larga cola. En todas estas variantes los felinos presentan largas fauces aserradas.

En este motivo la estructura del cuerpo, cuadrúpedo y con cola, permite identificarlo con un felino pero su cabeza está sustituida por una cabeza draconiforme, que remite al yacaré. Además, el cuerpo puede leerse como hibrido donde la mancha compuesta al estar reticulada (figura 4 a) puede referir a las serpientes y a los jaguares simultáneamente, mientras que la larga cola funciona como sinécdoque del puma (figura 4 a y b).

2-Draconiformes: este motivo, presente tanto en las piezas grabadas como en las pintadas, se define por la cabeza con los rasgos estables ya señalados, que remiten a la cabeza del yacaré. En la versión polícroma el ser draconiforme presenta esa cabeza unida a un cuerpo que puede tener variaciones. Generalmente es romboidal (posiblemente asociado al batracio) y forma con las cabezas un ser bicéfalo o pluricéfalo (figura 5 a). En la versión grabada este motivo configura guardas en las que las cabezas se enlazan y las fauces aserradas se multiplican y unen generando rombos y triángulos

11. Freiberg describe un yacaré negro (caiman yacare) que en la Argentina comparte su hábitat con el yacaré overo (caiman latirostris). 


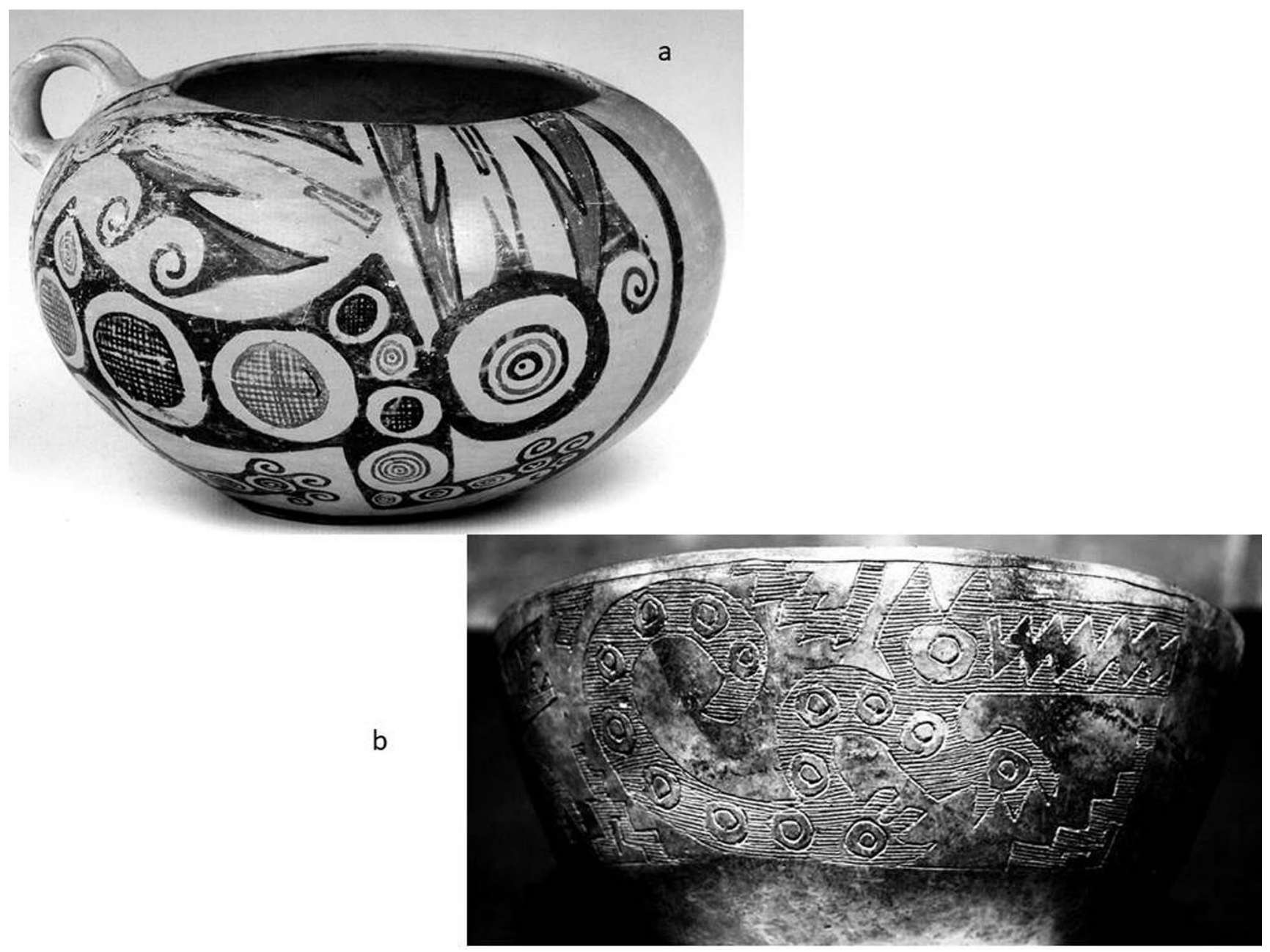

Figura 4: a-Jarra globular policromada (rojo y negro sobre ante), alto: $11 \mathrm{~cm}$, diámetro: 17, $6 \mathrm{~cm}$. Hualfín, Catamarca. Colección MNBA, Buenos Aires. b- Puco gris grabado, alto $11 \mathrm{~cm}$, diámetro: 11, $9 \mathrm{~cm}$. Sitio Airampo, Las Faldas, Belén, Catamarca. Colección IAM, Tucumán. Fotos: María Alba Bovisio.

aserrados (figura $5 \mathrm{~b}$ ). A mi juicio este motivo pone en juego asociaciones entre saurios, hidrosaurios y batracios $^{12}$.

3-Ofidio felínico draconiforme: este motivo aparece solo en jarras y pucos policromos, está definido por un cuerpo serpentino con las manchas compuestas y la cabeza draconiforme, que puede reiterarse en el remate de la cola constituyendo una suerte de serpiente bicéfala (figura 6 a). En este caso predominan las asociaciones entre hidrosaurios (yacarés) y serpientes (lampalaguas y yararás) que subsumen las referencias al jaguar a través de las manchas de círculos concéntricos y reticulados.

4- Felino ofídico-draconiformes: solo en la cerámica gris grabada hallamos este motivo caracterizado por un cuerpo caudrúpedo con forma serpentina, largas colas, y largas lenguas que rematan en cabezas draconiformes o cabezas triangulares que se pueden asociar a las de las serpientes (figura 6 b). Si en el motivo anterior los

12. En función de los alcances de este artículo focalicé en los principales animales que intervienen en la iconografía del Período Medio, pero cabe aclarar que a estos grandes cazadores (felinos, serpientes, hidrosaurios) se suman animales secundarios como los lagartos y los sapos. Sobre este tópico me he extendido en mi tesis doctoral (Bovisio 2008a). 


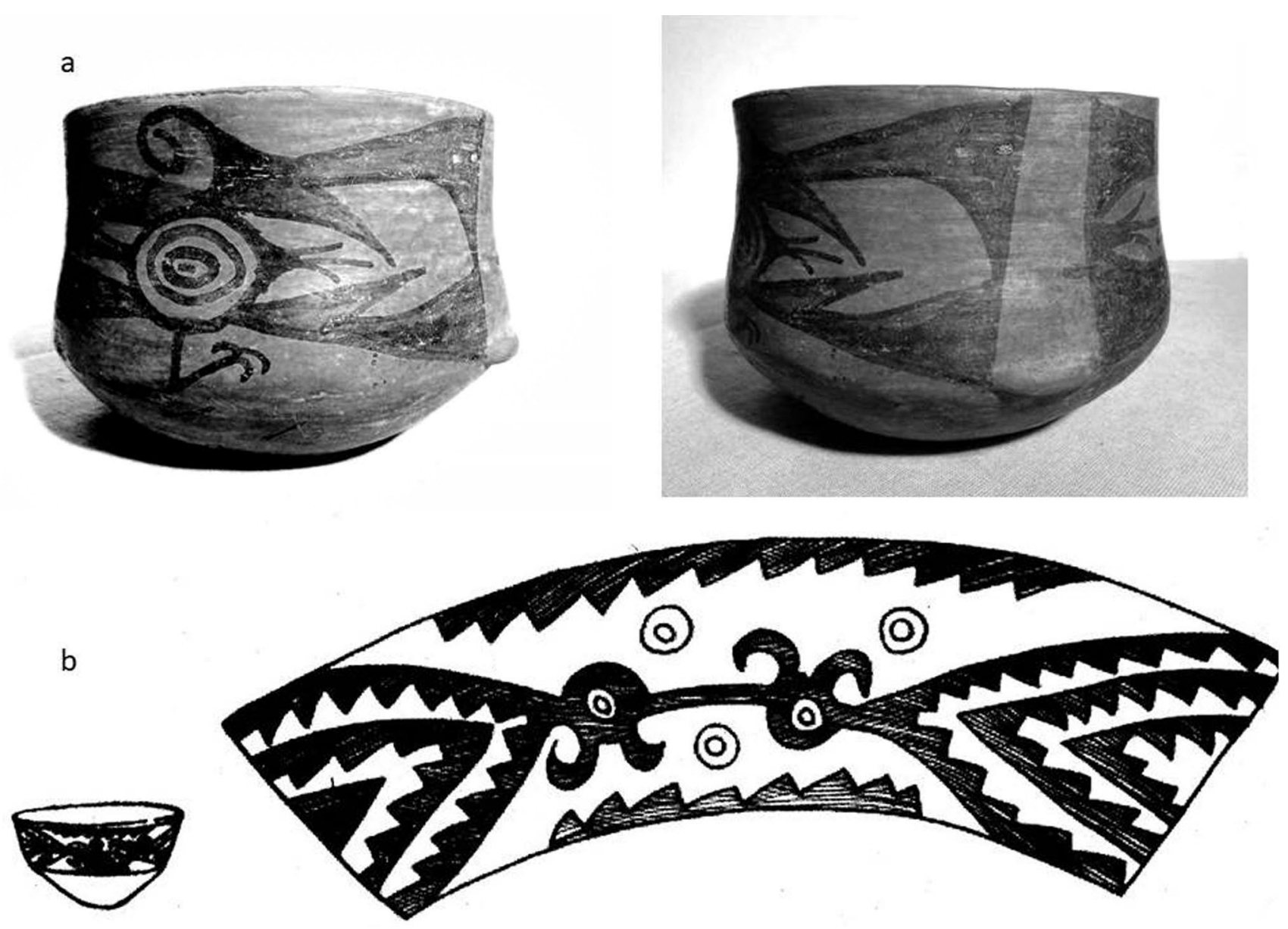

Figura 5: a- Puco policromo (rojo y borravino sobre ante), alto: $10 \mathrm{~cm}$, diámetro: $13 \mathrm{~cm}$. Hualfín, Catamarca. Colección MNBA, Buenos Aires. Foto: María Alba Bovisio. b- Pucos gris grabado, alto: $12 \mathrm{~cm}$. Cementerio Aguado Orilla Norte, Catamarca. Colección Muniz Barreto № 11678. Museo de La Plata. Dibujo: Ana Elsa Montes.

pintores enfatizaban la relación entre hidrosaurios y serpientes (subsumiendo en estos cuerpos al del jaguar), en esta quimera los grabadores expresan las identificaciones entre felinos y serpientes, los hidrosaurios quedan subordinados y se los refiere a través de cabezas draconiformes que aparecen en los remates de las colas y las lenguas.

5-Zoo-antropomorfos: este motivo aparece en las jarras policromas, se trata de un personaje con cuerpo felínico con las manchas de círculos concéntricos y reticulados, larga cola, que en la mayoría de los casos remata en cabeza draconiforme, y con cabeza antropomorfa con dos adornos circulares. Vale decir, que en el cuerpo felínico (de naturaleza híbrida porque presenta atributos serpentinos y draconiformes) la cabeza es sustituida por una cabeza antropomorfa, pero además, si bien este cuerpo remite al del felino por su carácter cuadrúpedo y manchado, está dispuesto en relación al soporte en la posición vertical propia del cuerpo humano, disposición que lo antropomorfiza (figura 7 a). En la cerámica gris grabada este motivo iconográfico se presenta sobretodo en pucos: cuerpo felino y cabeza antropomorfa (figura $7 \mathrm{~b}$ ).

En estas imágenes zoo-antropomorfas se expresan las relaciones de identificación entre el cuerpo de los felinos híbridos y el humano pero este queda subsumido en el cuerpo de aquellos.

6-Antropo-zoomorfos: solo en la cerámica gris grabada se da este motivo que consiste en cuerpo antro- 


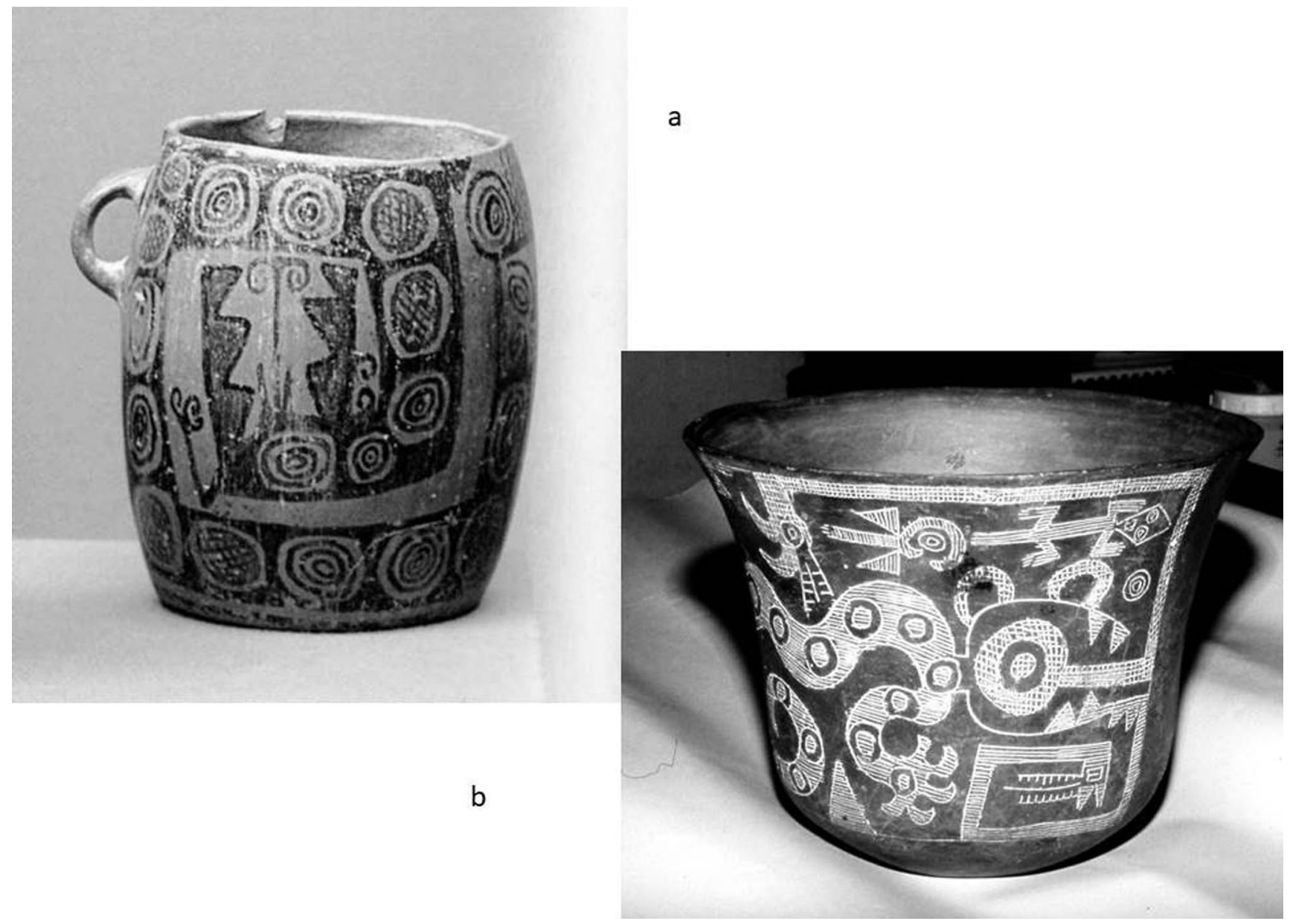

Figura 6: a-Jarra policroma (rojo y negro sobre ante), alto: $15 \mathrm{~cm}$, diámetro: 12, $4 \mathrm{~cm}$. Catamarca, Colección de la Cancillería Argentina. b- Puco negro grabado, alto: 14 cm., diámetro: 19,5 cm. Valle de Hualfín, Catamarca. Colección Museo Condorhuasi, Belén, Catamarca. Fotos: María Alba Bovisio.

pomorfo es decir, vertical y bípedo, que presenta atributos de reptil o de felino, cuerpo con retícula o con manchas, a de felino cuerpo con manchas y cuya cabeza es sustituida por una draconiforme ${ }^{13}$ (figura 8 a). En este caso los cuerpos zoomorfos quedan subsumidos en el del humano.

7-Variante antropo-zoo-antropomorfa: es un motivo muy particular porque expresa, a mi juicio, un equilibrio entre lo antropomorfo y lo zoomorfo de modo que ningún cuerpo subsume al otro, se trata de un ser configurado por un rostro antropomorfo con adornos circulares (igual al del zoo-antropomorfo) y cuerpo vertical, que remite a posición bípeda propia de lo humano, constituido por serpientes draconiformes que se disponen en una simetría axial especular. En la versión polícroma aparece exclusivamente en unas urnas globulares, cuyo tamaño oscila entre los 35 y $45 \mathrm{~cm}$ de diámetro ${ }^{14}$ (figura 8 b) que son piezas excepcionales, en tanto hasta el momento se han registrado solo seis

13. Algunos autores han interpretado este tipo de motivos como personajes disfrazados o enmascarados (Balesta y Zagorodny, 2002: 50) pero no existe ninguna evidencia que avale esta lectura de modo que nos limitamos a dar cuenta de su carácter híbrido.

14. Hemos relevado algunas que se reproducen con las mismas características pero en miniatura, este material aún está en proceso de estudio. 


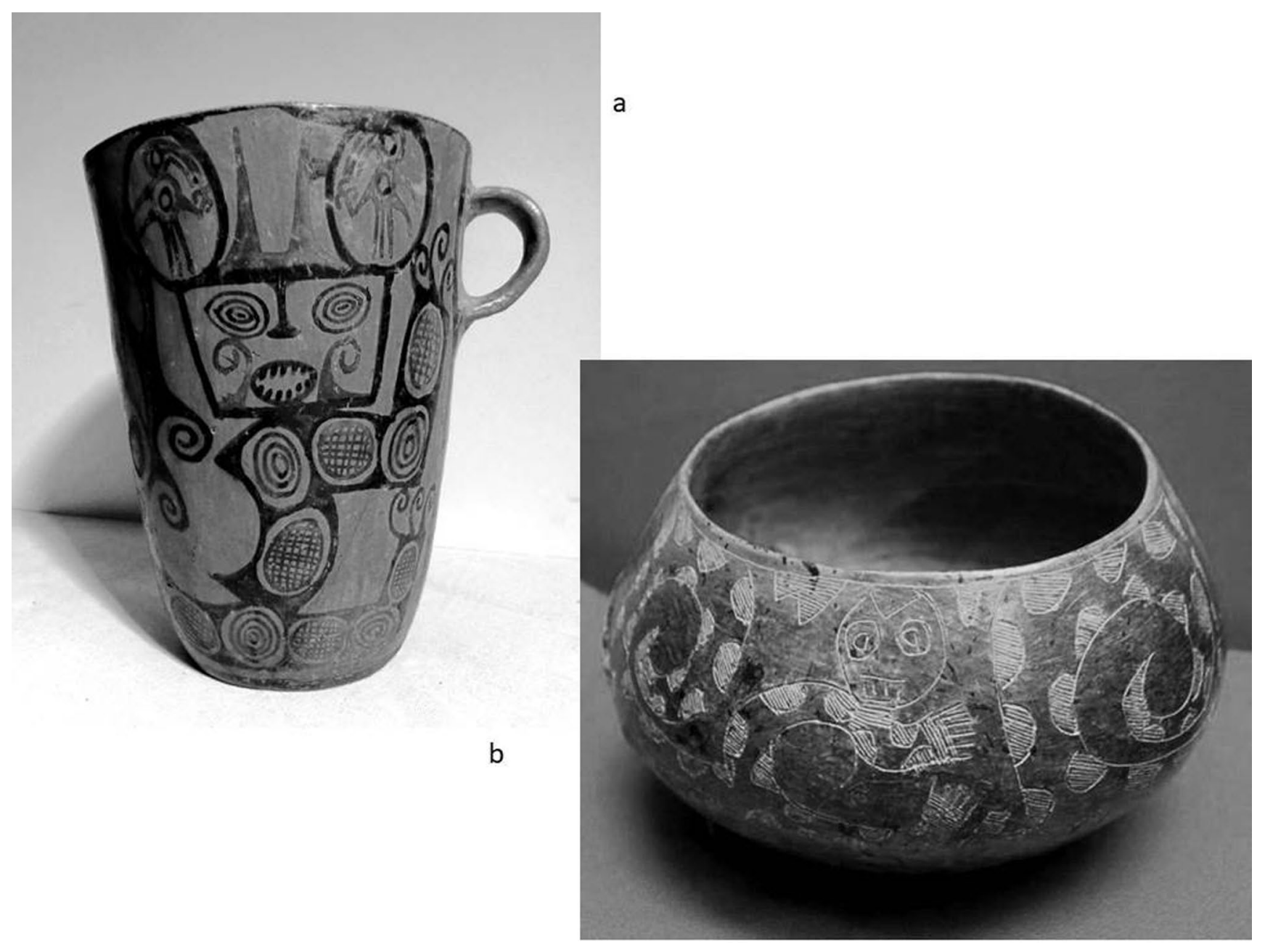

Figura 7: a-Jarra policromo (rojo y negro sobre ante), alto: 17 cm., diámetro: $12 \mathrm{~cm}$. Ex Colección MNBA, Buenos Aires. bPuco gris grabado, alto: 10 cm, diámetro: 19, 5 cm. Las Faldas, Belén, Catamarca. IAM, Tucumán. Fotos: María Alba Bovisio.

ejemplares. ${ }^{15}$ Lamentablemente en ninguna se conservó el contenido y solo se conoce el contexto de la que pertenece a la colección Muniz Barreto, procedente de la tumba 86 del Cementerio Aguada orilla norte (Sempé 1998). Si tomamos en cuenta la información contextual se puede afirmar que se trata de una pieza excepcional vinculada a la autoridad, ya que forma parte del ajuar funerario de un entierro individual que incluye una veintena de objetos de cerámica y un hacha de metal
(Sempé y Baldini, 2002: 258). Las hachas de metal también son objetos excepcionales y están realizadas con un material asociado a tecnologías de poder (Sempé op. cit., González 1998) su presencia sumada a la cantidad de objetos, a la urna, y al hecho de que se trate de una tumba individual, estarían indicando que el entierro correspondía a un personajes que detentaba una posición de prestigio en la comunidad. En la versión grabada, este motivo se da en pucos de los que contamos

15. Los ejemplares pertenecen a la ex-colección Di Tella, actualmente en el Museo Nacional de Bellas Artes, al Museo Chileno de Arte Precolombino de Santiago de Chile, al Museo Adán Quiroga de Catamarca, al Museo Condorhuasi de Belén (Catamarca), a la colección Puppo (Buenos Aires) y a la colección Muniz Barreto en el Museo de La Plata (Buenos Aires). González y Baldini han llamado la atención acerca de que estas urnas se asemejan formalmente a unas que contenían cadáveres de niños, hallazgos que se interpretaron como sacrificios rituales puesto que no hay entierros de párvulos en urnas en los cementerios aguada. En virtud de esa similitud, pese a que se desconoce el contenido que habrían guardado estas urnas, proponen que también pueden haberse utilizado para contener los cadáveres de niños sacrificados en determinados rituales muy extraordinarios, dada la escasa cantidad de ejemplares (González y Baldini 1991). 

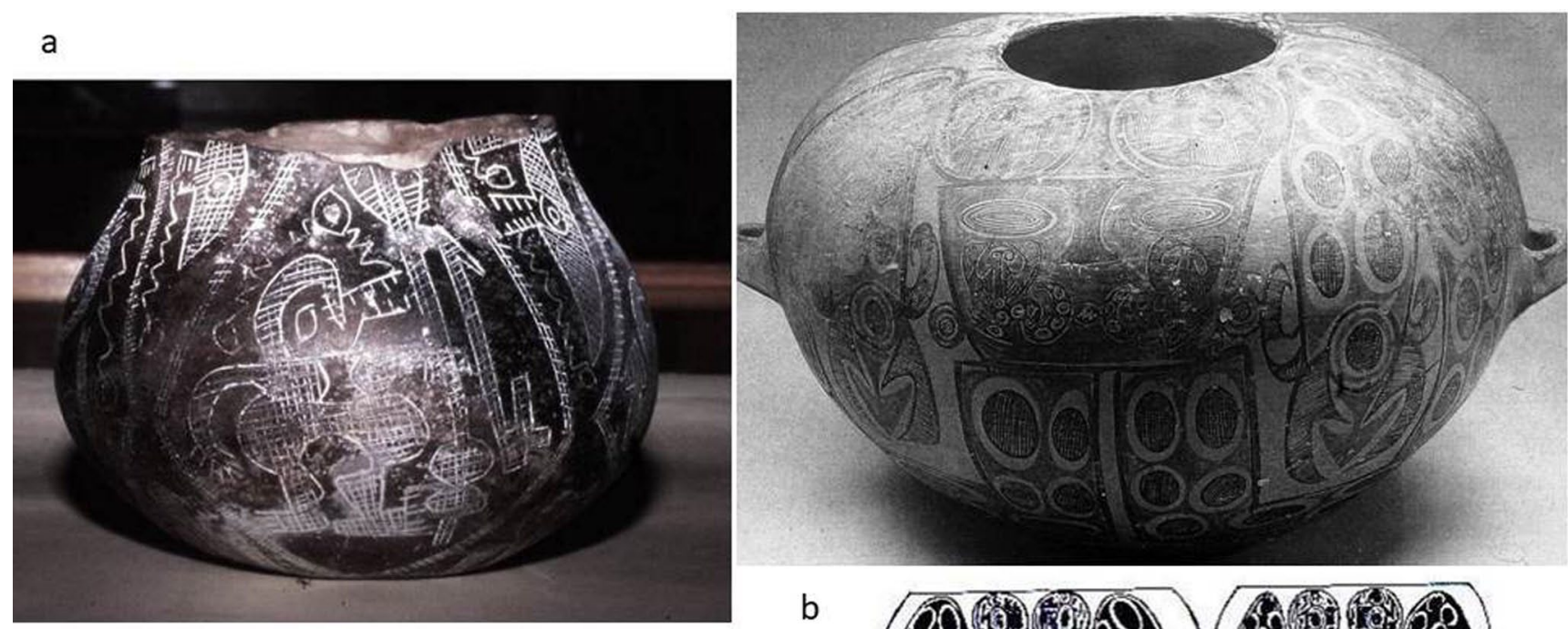

\section{b}
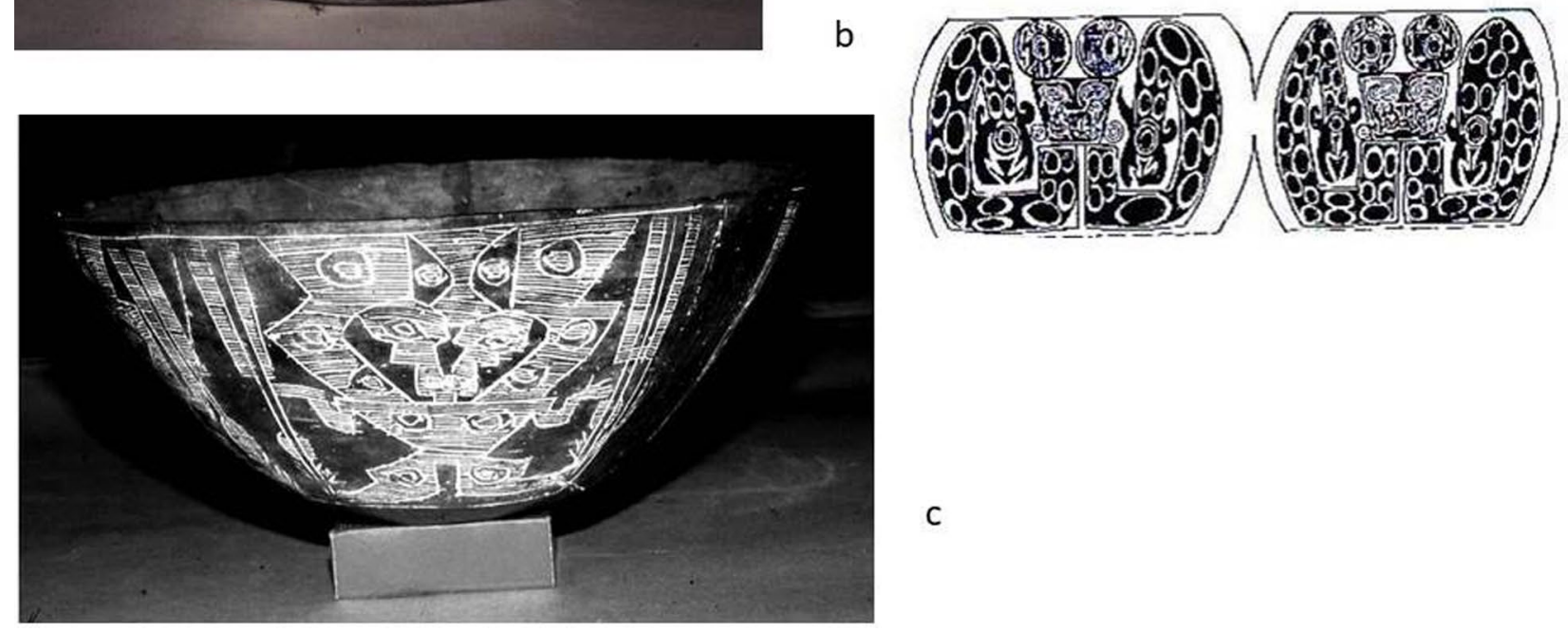

C

Figura 8: a- Vaso gris grabado: alto: $9 \mathrm{~cm}$., diámetro: $12 \mathrm{~cm}$. Museo Arqueológico Adán Quiroga, San Fernando del VaIle de Catamarca. b- Urna policroma (rojo y negro sobre ante); alto: $34 \mathrm{~cm}$., diámetro: $46 \mathrm{~cm}$. Museo Chileno de Arte Precolombino, Santiago de Chile. c- Puco gris grabado, alto: 9 cm., diámetro: $16 \mathrm{~cm}$. Belén, Catamarca. Museo Arqueológico Adán Quiroga, Catamarca. Fotos: María Alba Bovisio. Dibujo: tomado de González y Baldini 1991.

con pocos ejemplares (hasta el momento he contabilizado cuatro).

\section{7) Personajes antropomorfos con atributos zoo-} morfos: en este caso no se trata de una quimera por las características de la imagen que claramente puede identificarse con un cuerpo humano. Esta iconografía en Aguada Hualfín aparece solo en la cerámica grabada (figura 8 c) y está altamente formalizada, vale decir, se reitera una fórmula: personajes con tocados y trajes zoomorfos en los que predomina la disposición bípeda frontal, la estructura vertical especular, y el rostro en forma de corazón con ojos almendrados y bocas rectangulares o almendradas, que están portando emblemas como escudos y/o cetros o armas como estólicas, dardos o lanza (no contamos con materiales procedentes del registro arqueológico que nos permitan interpretar con certeza estos motivos) ${ }^{16}$.

16. Respecto al tema del "sacrificador", motivo que González identifica con un antropomorfo "que lleva como atributo una cabeza cercenada” y un "hacha o cuchillo" (González 1998: 218), solo se conoce hasta el momento un ejemplar, caracterizado por un antropomorfo que lleva en una de sus manos un conjunto de dardos o lanzas y en la otra una suerte de hacha y una cabeza antropomorfa. Razón por la cual entiendo que se trata de una iconografía excepcional frente a la reiteración, en cientos de piezas, de la fórmula del personaje con atributos. 
En la gris grabada predomina el humano con atributos de animales de poder, discurso iconográfico que probablemente estaba destinado a destacar el rol socio político y religioso de los curacas chamanes asociados a las wakas.

A partir de la descripción de los motivos iconográficos vemos que estos se distinguen entre sí por los modos diferenciados de poner en juego en su configuración un mismo repertorio de sinécdoques (manchas reticulares o de círculos concéntricos, fauces aserradas con largas lenguas, cuerpos bípedos, serpentinos, etc.) que refieren a la tríada humano, reptil, felino. Si partimos de la hipótesis, como ya mencioné, de que a partir de la experiencia que el hombre tiene de la naturaleza se configura un orden ontológico y cosmológico, entonces la confrontación con esos animales poseedores de capacidades suprahumanas sustentaría su identificación con el poder sagrado de las wakas, poder del que el chamán participa en el ritual de trasformación. Propongo como hipótesis interpretativa que los motivos antropo-zoomorfos y los zoo-antropomorfos aluden a la relación entre chamanes y wakas, las quimeras zoomorfas a la waka en sí de carácter multiforme, y los personajes con atributos al poder político-religioso del chamán a quien las wakas/ancestros han delegado la misión de ser autoridad ante su comunidad.

\section{Imágenes y saberes cosmológicos}

Hace ya varias décadas que el estudio de fuentes etnohistóricas andinas, tanto primarias como secundarias, referidas al culto a las wakas, me permitió proponer que este concepto de lo sagrado se corresponde con una cosmología fundada en un continuum ontológico entre todo lo viviente, continuum que implica una compleja red de equivalencias analógicas. En ese sentido, resulta sugerente la propuesta de Marconetto de pensar en la manchas de los jaguares de la cerámica Aguada del valle de Ambato (Catamarca) como "semillas de cebil-manchas", motivo que expresaría un núcleo complejo de sentidos que articula jaguar-cebil-transformación chamánica (Marconetto op. cit: 34). Desde una misma perspectiva podemos considerar la integración de las manchas del jaguar con las de las lampalaguas y las yararás, en la iconografía de Aguada Hualfín, como la manifestación de una identificación conceptual que equipara e integra a esas serpientes y esos felinos. Estas operaciones se ubican en las antípodas del paradigma de la zoología moderna -que clasifica a estos animales como pertenecientes a especies diferentes imposibles de homologarse- justamente porque están dando cuenta de una ontología claramente diferente a la ontología naturalista (sensu Descola 2005) y objetivista propia del Occidente moderno.

A través del análisis desarrollado más arriba, vimos que las imágenes de Aguada Hualfín se construyen a partir de la integración de sinécdoques y metáfora, operaciones retóricas que se fundan en la lógica de la analogía; la parte equivale al todo en la primera, y en la otra, se establece una paridad que justifica la sustitución de un término por otro. Concebir la realidad "por analogía" es afirmar una relación de correspondencia entre todos los aspectos y niveles de la realidad natural y social (Godelier 1974). En este sentido, podemos pensar a los motivos quiméricos como la expresión de una ontología analogista ${ }^{17}$ que integra a humanos y no-humanos en una red de correspondencias sistemáticas, en la que adquieren relevancia las similitudes morfológicas observables, manchas que permiten camuflarse a jaguares y serpientes, colmillos que se usan para el ataque y caza de presas, como así también, determinados comportamientos y capacidades, fuerza, agilidad, visión nocturna, etc.

Las quimeras zoomorfas expresarían una serie de integraciones analógicas de seres de la naturaleza (pumas, jaguares, yacarés, lampalaguas, yararás) en tanto materializan, a través de los "atributos de poder" mencionados, ideas que estarían asociadas con el poder de lo sagrado, lo waka. No se trata de imágenes de jaguares, yacarés, pumas, etc., sino de la expresión de lo $w a k a$, identificado con propiedades y capacidades de esos animales.

Pero además, en relación al concepto de orden cosmológico es significativo que los animales referidos pertenezcan, simultánea o excluyentemente, a los distintos pisos ecológicos del NOA, la sierra y la yunga: jaguar, yacaré pertenecen a las tierras bajas; puma, a las sierras, y

17. Estoy planteando una ontología analogista en términos diferentes a los de Descola, quien parte de la distinción entre "fisicalidad" e "interioridad" (Descola 2005: 190) puesto que considero que en el mundo andino es inviable tal distinción. Se trata, como señalé, de una ontología fundada en el principio de continunn ontológico, donde fisicalidad e interioridad son indiscernibles (véase al respecto Bovisio 2010), y donde se establecen relaciones de correspondencias entre humanos y no humanos a partir de propiedades, atributos, funcionamientos y conductas. 
lampalagua y yarará a ambos espacios. En la integración metonímica de los mismos se metaforiza la idea de centro integrador, unidad ordenadora que permite la complementariedad en la que se funda el funcionamiento del mundo andino. Esta integración se verifica en el registro arqueológico por la presencia de productos de una zona en la otra y viceversa; presencia que nos habla de la circulación e interacción entre objetos, seres, ideas, bienes materiales y simbólicos a la vez.

En cuanto a las imágenes quiméricas antropo-zoomorfas y zoo-antropomorfas, no estarían "describiendo la transformación chamánica” sino trasmitiendo el sustento ontológico de dicha práctica fundada en la relación entre el cuerpo del chaman y el de los animales con poderes suprahumanos. Al respecto la variación entre lo zoo-antropomorfo y lo antropo-zoomorfo podría estar asociada a conceptos en torno al proceso mismo de la transformación que acontece en un cuerpo de condición humana que abandona esta condición para asumir una suprahumana. Quizás, si el cuerpo híbrido zoomorfo encarna a la waka, el antropo-zoomorfo conceptualiza el inicio de la transformación, cuando aún lo humano subsume a lo animal, y el motivo zoo-antropomorfo, la culminación, cuando lo humano queda subsumido en lo animal pero sin desaparecer ${ }^{18}$.

En el caso de los personajes con atributos de animales de poder ("trajes", "tocados" con reticulados, manchas, crestas), como ya señalé, desde mi perspectiva de análisis no se trata de quimeras, pero considero que en el sentido de estas imágenes se ponen en juego relaciones de orden analógico que son las que sustentan las identificaciones entre atributos animales y poder sagrado. Vale decir, los "atributos animales" que detentan estos personajes pueden leerse como los emblemas que denotan el poder que les confieren las wakas (identificadas con los animales a los que corresponden dichos atributos).

La decodificación de esta compleja iconografía debió estar asociada a saberes cosmológicos trasmitidos oralmente ${ }^{19}$. Carlo Severi, a partir de su trabajo de campo entre los cunas de Panamá, señala que en la transferencia de saberes de los chamanes a sus discípulos se articulan cantos y pictografías: la percepción activa de un modo específico la memoria, y para que esto ocurra es necesario que las imágenes se inscriban en tradiciones iconográficas que pasan de generación en generación (Severi 2007). Para el caso de la producción aquí tratada le atribuyo un rol central a los hacedores de las piezas que construyen tradiciones plástico-iconográficas locales, vale decir, estilos propios que operan en cada valle de un modo particular.

En la descripción de los distintos motivos y sus variaciones en la cerámica policroma y en la grabada vimos que hay determinadas iconografías que solo se dan en una de las técnicas (los personajes antropomorfos con atributos zoomorfos, por ejemplo, aparecen solo en la cerámica grabada (figura $8 \mathrm{c}$ ), y en algunos casos, solo en determinado tipo de objetos (por ejemplo, el zoo-antropomorfo policromo aparece solo en las jarras (figura 7 a). No estoy aún en condiciones de plantear hipótesis acerca del porqué de estas exclusiones y especificidades pero sí puedo afirmar que están evidenciando la relevancia de quienes materializan discursos cosmológicos que adquieran sentidos específicos en ese proceso de materialización en que los hacedores elijen determinadas técnicas y materiales para configurar sus repertorios iconográficos.

\section{Epílogo}

Viveiros de Castro, a partir fundamentalmente de sus investigaciones con los arawetés en la Amazonia, postula el perspectivismo amerindio, cosmología en la que "es humano todo ser que ocupe la posición de sujeto cosmológico, todo existente puede ser pensado como pensante [...] es decir como " activado" o "agentado" por un punto de vista" (Viveiros de Castro 2010: 54). Ser capaz de ocupar un punto de vista es una cualidad del alma o espíritu que poseen tanto humanos como no- humanos de modo que la diferencia entre los puntos de vista no radica en el alma sino en el cuerpo. Los animales ven cosas diferentes de las que ven los humanos porque sus cuerpos son diferentes (op. cit: 55). Desde este paradigma las relaciones entre naturaleza y cultura estarían reemplazadas por las interacciones entre humanos y no-humanos definiéndose recíproca y excluyentemente puesto que

18. Agradezco a Nicolás Miranda, alumno del Posgrado de la Universidad de San Martin, cuya intervención en el debate en clase sobre uno de mis artículos me llevó a pensar en esta posible lectura.

19. Considero aplicable la hipótesis que planteara Rowe para el arte de Chavín cuando asocia las iconografías híbridas con los kenning, metáforas propias de la antigua poesía nórdica, donde la comparación por sustitución se funda en una convención arbitraria y compleja en la que juega un rol fundamental la transmisión oral del conocimiento a cargo de los poetas (Rowe 1972: 259) 
los no-humanos (animales, espíritus, difuntos) no pueden ver al hombre como humano en tanto se ven a sí mismos como tales.

Pero hay una excepción: los chamanes, cuya condición está determinada por su capacidad para "atravesar las barreras corporales y adoptar la perspectiva de subjetividades aloespecíficas de manera de administrar relaciones entre estas y los humanos" (op. cit.:40).

A mi juicio el perspectivismo amazónico no puede equipararse a la cosmología andina prehispánica pero existen convergencias significativas. Como indiqué más arriba, la información etnohistórica de los Andes centrales y área surandina, permite afirmar que la entidad sagrada waka se define por su naturaleza múltiple -animal, humano, manantial, piedra, fardo funerario, santuario, montaña, etc.- y por su capacidad de transformarse, condición ontológica transespecífica que aúna seres diversos, humanos y no-humanos (continnum ontológico). Propongo, entonces, que las quimeras zoomorfas podrían expresar el concepto de waka entidad sagrada identificada con los poderes y capacidades de la tríada felino-saurio-ofidio. Poderes y capacidades no humanas y supras-humanas de las que solo los chamanes pueden participar a través de la transformación vehiculizada por el consumo de plantas psicoactivas. En consecuencia podemos pensar que los zoo-antropomorfos y los antropo-zoomorfos, remitirían al cuerpo híbrido que asume los diversos puntos de vista humanos y nohumanos, corporalidad multiforme, propia de las wakas, y que puede ser adoptada solo por los chamanes que las encarnan en el momento del ritual ${ }^{20}$. Las variaciones entre los zoo-antropo y los antropo-zoo podrían vincularse, como mencioné, con distintos momentos o distintas formas que adquiere el proceso de transformación corporal que habilita puntos de vista humanos y no-humanos simultáneamente. En ese sentido, los antropomorfos con atributos zoomorfos (atributos asociados a animales de poder) posiblemente estén enfatizando el rol político religioso de los curacas-chamanes, como intermediarios indispensables entre las wakas y la comunidad, guardianes del orden cósmico por su capacidad de asumir una corporalidad múltiple.

Finalmente, quiero insistir en que los objetos portadores de estas iconografías cumplieron un papel central en la puesta en circulación de discursos en torno a los ordenes ontológico y cosmológico vigentes en los valles del NOA durante el Período Medio, pero no como meros "textos" sino como agentes que debieron tener roles activos en sus contextos de uso y circulación, vale decir, que no solo expresaban ontologías y cosmologías sino que las configuraban y en este proceso adquieren relevancia los hacederos de las piezas como verdaderos hacedores de ontologías y cosmologías, en otras palabras, hacedores de mundo.

Buenos Aires, septiembre 2019

\section{Bibliografía}

ARHEIM, R., 1985. El pensamiento visual. EUDEBA, Buenos Aires.

BALESTA, B. y N. ZAGORODNY, 2002. Los frisos antropomorfos en la cerámica funeraria de La Aguada de la Colección Muñiz Barreto. Estudios atacameños № 24: 39-50. San Pedro de Atacama.

BOVISIO, M. A., 2008a. De imágenes y misterios: el problema de la interpretación del "arte" prehispánico", tesis doctoral, Facultad de Filosofía y Letras, Universidad de Buenos Aires. M.S.

2008b. Metáforas animales: la iconografía del poder sagrado en la plástica prehispánica del NOA. II Simposio Internacional/ III Jornadas del GERE sobre Religiosidad, Cultura y Poder, Buenos Aires. CD Rom.

2010 "Muertos y muerte en el mundo andino prehispánico". Congresso Latino-americano de Ciências Sociais e Humanidades: Imagens da Morte, Universidade Salgado de Oliveira, Niteroi, Brasil,

2011. Las huacas andinas: lo sobrenatural viviente. En La imagen sagrada y sacralizada, P. Kriege (Ed), Vol. I, pp.53-85. UNAM, Instituto de Investigaciones Estéticas, México.

2012 a. La metáfora como principio estético en el arte prehispánico del Período de Integración del N.O. argentino. Expresiones Estéticas Prehispánicas. Boletim do Museu Paraense Emilio Goeldi: Ciências Humanas, 7/ 1: 559-576.

2012b. Acerca de wakas y chamanes: cuerpos híbridos en la cerámica del valle de Ambato (Catamarca, Argentina). En Somos de Barro, Somos de Piedra: Arqueología del Cuerpo en América Latina, C. Escalona y R. Navarrete (Eds), pp.173199. Verlag/Editorial Académica Española, Alemania.

2016. Acerca de la naturaleza de la noción de wak'a: objetos y conceptos. En Wak'as, diablos y muertos alteridades significantes en el mundo andino, L. Bugallo y M. Vilca (Eds.), pp.73-11. UNju/IFEA, San Salvador de Jujuy.

- 2017. Esculpir, pintar, grabar: consideraciones sobre las diversas tradiciones plásticas y la trasmisión de

20. Cabe insistir en que en la cosmología andina prehispánica no existe la distinción entre cuerpo y espíritu, configuran una unidad indisoluble, mientras que en la concepción amazónica es el espíritu el que asume determinada corporalidad en el viaje chamánico. 
significados cosmológicos durante el Período Medio del Noroeste Argentino (450-900 d.C.). Ponencia presentada en el Simposio: Materialidades, texturas y colores en los Andes. Un abordaje desde la Antropología. XXXV International Congress of the Latin American Studies Assocation. MS.

2019. Representaciones y "presentificaciones": funciones de la imagen plástica en el mundo andino prehispánico. Culturas visuales indígenas en las Américas desde la antigüedad hasta el presente. Estudios Indiana 13: 241-266, Berlín.

CABRERA, A., 1961. Los felinos vivientes de la República Argentina. Revista del Museo Argentino de Ciencias Naturales "Bernardino Rivadavia" e Instituto Nacional de Investigación de las Ciencias Naturales, VI, 5:161-247.

CRUZ, P., 2005 Hombres complejos y señores simples. Reflexiones en torno a los modelos de organización social desde la arqueología el valle del Ambato (Catamarca). En Actas del taller: Procesos sociales prehispánicos en los Andes Meridionales, A. Nielsen (Ed), pp.67-89. Tilcara.

DESCOLA, P., 2005 Par-delà la nature et la culture. Gallimard, Bibliothèque des sciences humaines, Paris.

2006 La Fabrique des images. Anthropologie et Sociétés, 30-3 : pp.167-182.

2011 La Fabrique des images. Visions du monde et formes de la représentation. Somogy Editions D’art, Paris.

FRANCASTEL, P., 1970 La Realidad Figurativa. EMECE, Buenos Aires [1 1 a edición en francés 1965].

FREIBERG, M., 1954 Vida de batracios y reptiles sudamericanos. Cesarini Hermanos Editores, Buenos Aires.

GELL, A., 1998 Art and Agency. An Anthropological Theory. Clarendon Press, Oxford.

GODELIER, M., 1974. Economía, fetichismo y religión en las sociedades primitivas. Siglo XXI, Madrid.

1989 Lo ideal y lo material. Taurus, Madrid. Edición original en francés 1984.

GONZÁLEZ, A. R., 1964. La cultura de la Aguada de N.O. argentino. Revista del Instituto de Antropología de la Universidad Nacional de Córdoba, .2-3: 204-253.

— 1998. Cultura La Aguada. Arqueología y diseños. Filmediciones Valero, Buenos Aires.

GONZALEZ, A. R. y BALDINI, M. I. ,1991. Función y significado de un ceramio de la cultura La Aguada: ensayo de interpretación. Boletín del Museo Chileno de Arte Precolombino 5:23-52.

GORDILLO, I. 2007. Detrás de las paredes... Arquitectura y espacios domésticos en el área de La Rinconada (Ambato, Catamarca). En Procesos Sociales Prehispánicos en los Andes Meridionales: Perspectivas desde la casa, la comunidad y el territorio, A. E. Nielsen et alt. (Comp.), pp. 65-98. Editorial Brujas, Córdoba.

2013. Eso que llamamos Aguada su lugar en la Arqueología del Noroeste argentino. M.S.
2018. Los pueblos de la Aguada; vida y arte. Corpus Antiquitatum Americanensium, 9. Academia Nacional de Historia. Buenos Aires.

KUBLER, G., 1988. La configuración del tiempo. Nerea, Madrid. [1 1 a edición en inglés 1962]

LAGUENS, A., 2006. Continuidad y ruptura en los procesos de diferenciación social en comunidades aldeanas del valle de Ambato, Catamarca, Argentina (S.IV-X d.C.). CHUNGARÁ 382: 211-222.

LATOUR, B., 2008. Reensamblar lo social: una introducción a la teoría del actor-red. Ediciones Manantial, Buenos Aires.

LLAMAZARES, A. M., 2000 Arte chamánico del antiguo noroeste argentino, Visión Chamánica 1-3: 44-50.

MARCONETTO, M.B., 2015. El jaguar en flor representaciones de plantas en la iconografía Aguada del Noroeste argentino. Boletín del Museo Chileno de Arte Precolombino 201: 29-37.

NUÑEZ REGUEIRO, V. y TARTUSI, M., 1987. Aproximación al estudio del área pedemontana de Sudamérica. Cuadernos del Instituto Nacional de Antropología 12: 125-160.

2002. Aguada y el Proceso de Integración Regional. Estudios atacameños 24:. 22-34.

PEREZ GOLLÁN, J.A. 1994. El proceso de integración en el valle de Ambato: complejidad social y sistemas simbólicos. $R U$ MITACANA 1-1: 33-43.

PEREZ, J. A. y GORDILLO, I., 1993. Religión y alucinógenos en el antiguo Noroeste argentino. Ciencia Hoy 4- 22: 45-58.

PEREZ, J.A. y HEREDIA, O.R., 1991. Hacia un replanteo de la cultura de la Aguada". Cuadernos del Instituto Nacional de Antropología 12:161-177.

ROWE, J., 1972. El arte de Chavín; estudio de su forma y su significado. Historia y Cultura, Museo Nacional de Cultura, 6, Lima [1aㅡ edición en inglés 1969].

RYDÉN, S., 1944. Contribution to the archaeology Loa region. Gotenborg. Elan ders Boktryckeri Actiebolag.

SEMPÉ, M. C., 1998. Contacto cultural en el sitio Aguada orilla norte. En Homenaje a Alberto Rex González, pp.255-283. Facultad de Filosofía y Letras, Buenos Aires.

SEMPÉ, M. C. y BALDINI, M., 2002. Contextos temáticos y ordenamientos funerarios en el cementerio Aguada orilla norte. Relaciones de la Sociedad Argentina de Antropología XXVII: pp.247-269.

SEVERI, C. 2007. Le principe de la chimère. Une anthropologie de la mémoire. Éditions Rue d'Ulm - Musée du Quai Branly. Paris.

URTON, G. (Ed.), 1985. Animal myths and metaphors in South America. University of Utah Press. USA.

VIVEIROS DE CASTRO, E., 2010. Metafísicas caníbales. Líneas de antropología posestructural. Katz, Buenos Aires. 